\title{
Karakteristik Bioadsorben dari Limbah Kulit Durian untuk Penyerapan Logam Berat Fe dan Zn pada Air Sumur
}

\author{
Characteristic of Bioadsorbent from Durian Skin Waste for Heavy Metal Adsorption \\ Fe and Zn on Well Water
}

\author{
Sukma Budi Ariyani \\ Baristand Industri Pontianak \\ Kementerian Perindustrian \\ Pontianak, Indonesia \\ sukma-ariyani@kemenperin.go.id
}

\begin{abstract}
Abstrak-Kulit durian apabila tidak dimanfaatkan dan menumpuk akan mencemari lingkungan. Kulit durian dapat dimanfaatkan menjadi bioadsorben logam berat karena kulit durian memiliki kandungan selulosa yang tinggi. Penelitian ini bertujuan memanfaatkan limbah kulit durian sebagai bioadsorben logam berat $\mathrm{Fe}$ dan $\mathrm{Zn}$ pada air sumur, mengetahui karakteristik kulit durian sebagai bioadsorben logam berat dan mengetahui efektifitas bioadsorben dari kulit durian dalam menyerap $\mathrm{Fe}$ dan $\mathrm{Zn}$ pada air sumur. Metode penelitian yang dilakukan meliputi pembuatan bioadsorben dari kulit durian, pengujian karakteristik bioadsorben dari kulit durian seperti uji SEM+EDS, pencampuran bioadsorben dengan air sumur dan pengukuran kadar akhir logam. Hasil uji kadar air bioadsorben yang diperoleh sebesar 10,61\% dan kadar abu sebesar $1,04 \%$. Karakteristik fisik, bioadsorben yang dihasilkan memiliki ukuran pori yang beragam dan komposisi kimia nya meliputi senyawa $\mathrm{C}$, $\mathrm{O}, \mathrm{Ca}, \mathrm{K}$ dan Na. Bioadsorben dari kulit durian dapat menyerap logam berat $\mathrm{Zn}$ dan Fe hingga kadar akhir logam $\mathrm{Zn}$ mencapai < $0,001 \mathrm{mg} / \mathrm{L}$ dan kadar akhir logam Fe mencapai $0,169 \mathrm{mg} / \mathrm{L}$.
\end{abstract}

Kata kunci-bioadsorben, karakteristik, kulit durian, logam berat

Abstract-Durian skin if not used and piled up will pollute the environment. Durian skin can be used as a heavy metal bioadorbent because durian skin has a high cellulose content. This study aims to utilize durian skin waste as bioadsorbent of heavy metals $\mathrm{Fe}$ and $\mathrm{Zn}$ in well water, determine the characteristics of durian skin as a heavy metal bioadorbent and determine the effectiveness of bioadsorbent from durian skin in absorbing $\mathrm{Fe}$ and $\mathrm{Zn}$ in well water. The method of research included making bioadsorbents from durian skin, testing the bioadsorbent characteristics of durian skin such as SEM+EDS, mixing bioadorborbent with well water and measuring the final grade of metal. The water content test bioadsorbent results were $10.61 \%$ and ash content was $1.04 \%$. Physical characteristics, the bioadorbent produced has various pore sizes and its chemical composition includes compounds $\mathrm{C}, \mathrm{O}, \mathrm{Ca}, \mathrm{K}$ and $\mathrm{Na}$. Bioadsorbent from durian skin can absorb $\mathrm{Zn}$ and $\mathrm{Fe}$ heavy metals until the final content of $\mathrm{Zn}$ metal reaches $<0.001 \mathrm{mg} / \mathrm{L}$ and the final content of $\mathrm{Fe}$ metal reaches $0.169 \mathrm{mg} / \mathrm{L}$.

Keywords-bioadsorben, characteristic, durian skin, heavy metal

\section{PENDAHULUAN}

Buah durian merupakan salah satu buah lokal bersifat musiman yang membanjiri Kota Pontianak pada setiap tahunnya.

TABEL 1. Produksi DuRIAN Di Kalimantan Barat TAHUN 2016-2017

\begin{tabular}{lccc}
\hline Buah & 2016 (Ton) & 2017 (Ton) & Pertumbuhan (\%) \\
\hline Durian & 11,676 & 15,022 & 28,65 \\
\hline
\end{tabular}

Dapat dilihat dari Tabel 1, bahwa produksi buah durian di Kalimantan Barat mengalami kenaikan sebesar 28, 65\%.

Buah durian yang termanfaatkan selama ini hanya daging buah, sedangkan sisanya berupa kulit buah selama ini dibuang begitu saja tanpa pengolahan khusus, dan cenderung bercampur dengan sampah anorganik. Fenomena ini menimbulkan permasalahan baru, yaitu munculnya timbulan sampah organik yang berasal dari sisa buah-buahan yang tidak termakan seperti kulit durian. [1]

Kandungan daging buah durian merupakan 20-35\% dari berat buah, sedangkan bijinya $5-15 \%$, sisanya berupa kulit 60 $75 \%$. [2]

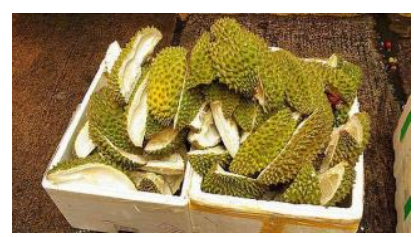

Gambar 1. Kulit Durian 
Sampah kulit durian seperti pada Gambar 1, apabila tidak dikelola dengan baik akan menimbulkan masalah bagi lingkungan, yaitu menjadikan lingkungan kotor dan kulit durian yang membusuk menimbulkan bau yang tidak enak.[3]

Kulit buah durian mengalami proses degradasi atau pembusukan yang lama, dikarenakan kandungan selulosa yang tinggi. Kulit durian memiliki kandungan selulosa yang tinggi sebanyak 50-60\% dan lignin serta kandungan pati yang rendah masing-masing sebanyak 5\%, sehingga proses pendegradasiannya lama.[4] Anindyawati juga menyatakan bahwa kulit buah merupakan limbah sisa hasil pertanian dengan kandungan lignoselulosa yang kompleks.[5]

Di sisi lain diketahui bahwa material lignoselulosa memiliki kemampuan menyerap logam berat karena mengandung gugus-gugus aktif seperti $\mathrm{OH}$ dan $\mathrm{COOH}[6,7]$ Tingkat pencemaran air oleh logam berat kini semakin tinggi karena pertumbuhan industri dan teknologi yang makin meningkat.

Adsorpsi adalah proses perpindahan massa pada permukaan pori-pori dalam butiran adsorben. Perpindahan massa yang terjadi melalui batas antara dua fasa yaitu: gaspadat, cair-padat. Proses yang terjadi selama adsorpsi yaitu perpindahan massa dari cairan ke permukaan butir, difusi dari permukaan butir ke dalam butir melalui pori, perpindahan massa dari cairan dalam pori ke dinding pori dan adsorpsi pada dinding pori. Sedangkan adsorben adalah bahan padat dengan luas permukaan dalam yang sangat besar. Permukaan yang luas ini terbentuk karena banyaknya pori pori yang halus pada padatan tersebut. [8]

Air adalah suatu kebutuhan esensial manusia yang kedua setelah udara untuk keperluan hidupnya. Manusia hanya bisa bertahan hidup kurang lebih 3 hari tanpa air. Untuk meciptakan suatu lingkungan hidup manusia yang bersih dan sehat tanpa persediaan air yang cukup, mustahil akan terjadi. Persediaan air yang banyak dan kualitas yang lebih baik akan meningkatkan derajat kesehatan masyarakat.

Air yang dibutuhkan air yang bersih dan hygiene, serta memenuhi syarat kesehatan yaitu air yang jernih, tidak berwarna, dan tidak berbau. Konsekuensi dari penggunaan air yang tidak bersih dan hygiene akan mengganggu kesehatan bagi yang mengkonsumsinya. Air yang berkualitas meliputi kualitas fisik, kimia, dan bebas dari mikroorganisme. [9]

Ciri air sumur yang mengandung logam $\mathrm{Fe}$ diantaranya adalah secara fisik air berwarna kuning dan sedikit berasa. Air sumur di daerah Siantan Kota Pontianak memiliki warna kuning kecoklatan. Air sumur ini digunakan masyarakat di sekitarnya untuk keperluan mandi dan mencuci.

Logam berat pada kadar tertentu tergolong limbah B3 yang dapat membahayakan lingkungan sekitarnya karena bersifat toksik bagi hewan dan manusia. Logam berat dapat menyebabkan kanker paru-paru, kerusakan hati (liver) dan ginjal, jika kontak dengan kulit menyebabkan iritasi dan jika tertelan dapat menyebabkan sakit perut dan muntah.

Pencemaran logam berat dalam lingkungan bisa menimbulkan bahaya bagi kesehatan, baik pada manusia, hewan, tanaman maupun lingkungan. Logam berat dapat masuk dan terakumulasi ke dalam tubuh manusia melalui rantai makanan, minuman, atau melalui udara.

Kadar Fe yang lebih dari $1 \mathrm{mg} / \mathrm{l}$ dalam air akan menyebabkan terjadinya iritasi pada mata dan kulit. Apabila kelarutan besi dalam air melebihi $10 \mathrm{mg} / \mathrm{l}$ akan menyebabkan air berbau seperti telur busuk. Debu Fe juga dapat diakumulasi dalam alveoli dan menyebabkan berkurangnya fungsi paruparu. [10]

Besi dan zink dibutuhkan oleh tubuh sebagai nutrisi. Tubuh membutuhkan $7-35 \mathrm{mg}$ unsur besi tiap hari, $10-15$ mg unsur zink per hari. [11] Walaupun unsur-unsur tersebut diperlukan oleh tubuh, tetapi jika melebihi kebutuhan maka akan menimbulkan masalah bagi kesehatan. Besi mengakibatkan kerusakan pada dinding usus halus. Zink yang memiliki toksisitas rendah mengakibatkan muntaber. [12]

Penelitian ini bertujuan untuk memanfaatkan limbah kulit durian sebagai bioadsorben logam berat pada air sumur (khusunya logam $\mathrm{Fe}$ dan $\mathrm{Zn}$ ), mengetahui karakteristik bioadsorben dari kulit durian dan mengetahui efektivitas bioadsorben dalam menyerap logam berat tersebut.

\section{BAHAN DAN METODE}

Bahan yang digunakan adalah kulit durian, $\mathrm{HCl}$ Pro Analisis 0,1 N merk Merck, air sumur dari daerah Siantan Pontianak, aquadest.

Alat yang digunakan diantaranya magnetik stirer, blender, baskom, pisau, botol kaca sampel, beaker glass, erlenmeyer, corong, kain saring, kertas saring, AAS dan oven.

\section{A. Pembuatan Bioadsorben}

Kulit durian dicuci hingga bersih, dipotong kecil-kecil dan dikeringkan. Kemudian diblender, diayak dengan saringan 40 mesh dan diambil hasil serbuknya. Kemudian biomassa tersebut dipreparasi terlebih dahulu dengan merendam biomassa menggunakan $\mathrm{HCl} 0,1 \mathrm{~N}$ selama 24 jam.

Endapan disaring dengan kain saring dan dicuci dengan akuades hingga 3 kali pencucian. Biomassa dikeringkan dalam oven dengan suhu $100^{\circ} \mathrm{C}$ selama 24 jam. Kemudian hasilnya dihaluskan agar berupa serbuk bioadsorben.

Bioadsorben yang diperoleh, selanjutnya diuji terlebih dahulu kadar air dan kadar abu. Selain itu juga dilakukan uji SEM+EDS di Laboratorium SEM Fakultas MIPA Institut Teknologi Bandung (ITB).

\section{B. Pengujian Kadar Air dan Kadar Abu Bioadsorben}

Prosedur penetapan kadar air dan kadar abu mengacu pada Standar Nasional Indonesia (SNI) 06-3730-1995 tentang syarat mutu dan pengujian arang aktif. Arang aktif juga berfungsi sebagai bahan penyerap (adsorben). 


\section{Proses Pencampuran Air Sumur dengan Bioadsorben dari Kulit Durian}

2 gr dari bioadsorben yang diperoleh dimasukkan ke dalam $200 \mathrm{ml}$ air sumur. Diaduk dengan magnetic stirer kecepatan tetap selama 150 menit. Didiamkan selama 15 menit agar mengendap. Disaring dan dipisahkan dengan endapannya. Kemudian filtratnya diuji kadar besi ( Fe) dan seng $(\mathrm{Zn})$ akhir.

\section{Pengujian Kadar Logam}

Sampel yang diperoleh diuji kadar besi (Fe) dan seng (Zn) dengan menggunkanan alat Atomic Absorption Spectroscopy (AAS). Pengujian dilakukan di Laboratorium Air Balai Riset dan Standardisasi Industri Pontianak.

\section{HASIL DAN PEMBAHASAN}

\section{A. Kadar Air dan Kadar Abu Bioadsorben}

Pada Tabel 2. dapat dilihat bahwa kadar air bioadsorben dari kulit durian memenuhi syarat mutu penyerap, dimana syarat mutu menetapkan maksimal $15 \%$ dan hasil uji kadar air bioadsorben dari kulit durian sebesar 10,61\%.

Kandungan air pada adsorben yang besar dapat menurunkan kualitas dari daya adsorpsi yang dimilikinya. [13]

Sedangkan untuk kadar abu bioadsorben dari kulit durian dilihat pada Tabel 2. yakni $1,04 \%$ memenuhi syarat mutu penyerap yakni maksimal $10 \%$.

Penentuan kadar abu pada bioadsorben yang diperoleh berhubungan erat dengan kandungan mineral yang terdapat dalam suatu bahan, kemurnian serta kebersihan suatu bahan yang dihasilkan. Keberadaan abu yang berlebih dapat menyebabkan terjadinya penyumbatan pori-pori pada permukaan bioadsorben, sehingga luas permukaan menjadi berkurang. [14]

TABEL 2. HASIL UJI BIOADSORBEN

\begin{tabular}{cccc}
\hline No. & Parameter & $\begin{array}{c}\text { Hasil Uji } \\
(\%)\end{array}$ & $\begin{array}{c}\text { Syarat Mutu Penyerap } \\
\text { (SNI 06-3730-1995) }\end{array}$ \\
\hline 1. & Kadar Air & 10,61 & Maks. 15 \\
\hline 2. & Kadar Abu & 1,04 & Maks. 10 \\
\hline
\end{tabular}

\section{B. Analisis Komponen Kimia Penyusun Bioadsorben} Menggunakan SEM-EDS

SEM (Scanning Electron Microscopy) dipakai untuk mengetahui struktur mikro suatu material meliputi tekstur, morfologi dan komposisi partikel.

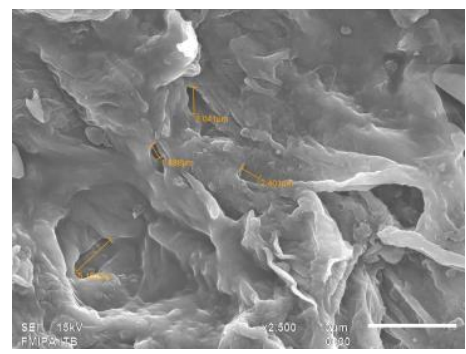

Gambar 2. Hasil Karakterisasi Bioadsorben Menggunakan SEM

Morfologi yang diamati oleh SEM berupa bentuk, ukuran dan susunan partikel. Analisis SEM hasil penelitian perbesaran 2500x diperlihatkan pada Gambar 2. Pada Gambar terlihat bentuk morfologis bioadsorben dari kulit durian mempunyai tektur yang tidak merata, ukuran rongga/ pori di antara 1,6885,151 $\mu \mathrm{m}$. Rongga yang dimiliki pada permukaan adsorben memungkinkan untuk terjadinya proses penyerapan, dimana larutan akan memenuhi permukaan adsorben dan mengisi rongga yang kosong sehingga terjadi interaksi antara dinding sel adsorben dengan larutan. Adanya pori-pori pada permukaan adsorben diperlukan untuk menghilangkan ion logam berat dalam air. [15]

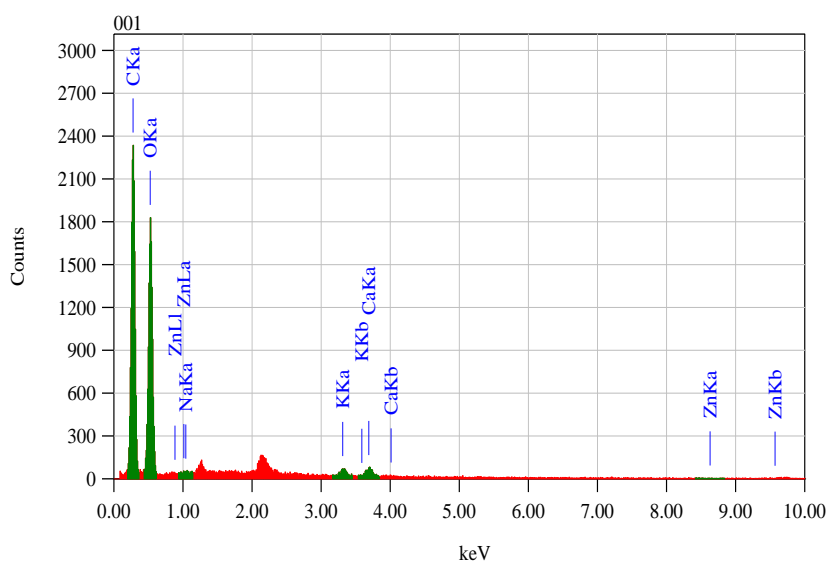

Gambar 3. Grafik EDS Bioadsorben Kulit Durian

TABEL 3. HASIL SEM-EDS BIOADSORBEN DARI KULIT DURIAN

\begin{tabular}{cccccc}
\hline \multirow{2}{*}{ Nama Sampel } & \multicolumn{5}{c}{ \% Massa Komposisi Kimia } \\
\cline { 2 - 6 } & $\mathrm{C}$ & $\mathrm{O}$ & $\mathrm{Na}$ & $\mathrm{K}$ & $\mathrm{Ca}$ \\
\hline $\begin{array}{l}\text { Bioadsorben } \\
\text { Kulit Durian }\end{array}$ & 58,34 & 40,64 & 0,05 & 0,41 & 0,54 \\
\hline
\end{tabular}

Analisis komposisi kimia dari permukaan adsorben secara kuantitatif dan kualitatif dilakukan menggunakan EDS (Energy Dispersive Spectroscopy) yang ada pada alat SEM. Persentase massa dari elemen-elemen kimia yang terkandung dalam bioadsorben kulit durian dapat dilihat pada Gambar 3 dan Tabel 3.

Dari hasil uji EDS diketahui komponen terbesar dalam bioadsorben kulit durian adalah komponen $\mathrm{C}$ dan O. Diketahui bahwa kulit durian memiliki kandungan selulosa yang tinggi. 
Struktur kimia selulosa seperti pada Gambar 4. terlihat bahwa komponen utama penyusun utama nya adalah komponen $\mathrm{C}, \mathrm{O}$ dan $\mathrm{H}$. Selulosa memiliki gugus aktif $\mathrm{OH}$ yang mampu mengikat logam berat.

Metode adsorpsi umumnya terjadi berdasarkan interaksi antara logam dengan gugus fungsional yang ada pada permukaan adsorben melalui interaksi pembentukan kompleks dan biasanya terjadi pada permukaan padatan yang kaya akan gugus fungsional seperti - $\mathrm{OH},-\mathrm{NH},-\mathrm{SH}$ dan $-\mathrm{COOH}$. [16]

Gugus aktif yang terdapat pada bioadsorben kulit durian inilah yang mampu menyerap logam berat. Penyerapan yang terjadi adalah adsorbsi kimia dimana terjadi karena ikatan sangat kuat antara adsorbat dan adsorben sehingga sulit untuk dilepaskan dan prosesnya hampir tidak mungkin terjadi bolak balik.[17]

Hal ini diperkuat dengan hasil penelitian terdahulu, bahwa spektrum FTIR karbon aktif dari kulit durian yang tidak diaktivasi menunjukkan adanya vibrasi gugus fungsi O-H, C$\mathrm{H}$, C-C dan $\mathrm{C}=\mathrm{C}$ dari senyawa aromatik yang ditunjukkan dengan adanya pita serapan di daerah panjang gelombang $455.2 \mathrm{~cm}^{-1}-3402.43 \mathrm{~cm}^{-1}$. [18]

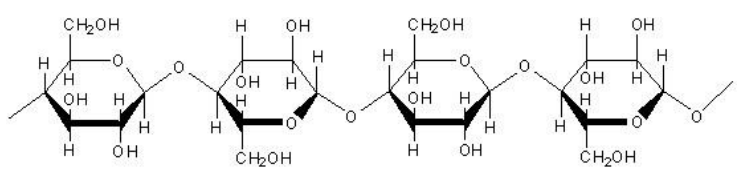

Gambar 4. Struktur Selulosa

\section{Penyerapan Logam Berat Fe dan Zn pada Air Sumur}

Hasil uji kadar logam berat Fe dan Zn pada air sumur dapat diliat pada Tabel 4 .

TABEL 4. HASIL UJI KADAR LOGAM

\begin{tabular}{ccc}
\hline Logam Berat & $\begin{array}{c}\text { Kadar Awal } \\
(\mathrm{mg} / \mathrm{L})\end{array}$ & $\begin{array}{c}\text { Kadar Akhir } \\
(\mathrm{mg} / \mathrm{L})\end{array}$ \\
\hline Besi $(\mathrm{Fe})$ & 0,198 & 0,169 \\
\hline Seng $(\mathrm{Zn})$ & 0,032 & $<0,001$ \\
\hline
\end{tabular}

Kadar awal pada tabel diperoleh dari hasil uji kadar awal logam Fe dan Zn yang terkandung pada air sumur yang diambil dari daerah Siantan Pontianak Kalimantan Barat.

Dari hasil tabel di atas dapat diliat penurunan yang terjadi setelah pencampuran dengan bioadsorben dari kulit durian.

Untuk logam berat seng ( $\mathrm{Zn})$, penyerapannya hingga mencapai $<0,001 \mathrm{mg} / \mathrm{L}$, yang bisa dikatakan bioadsorben mampu menyerap seluruh ion $\mathrm{Zn}$. Sedangkan logam berat besi $(\mathrm{Fe})$, penyerapannya hingga $0,169 \mathrm{mg} / \mathrm{L}$, yakni $15 \%$ penyerapan dari kadar awal Fe.

\section{KESIMPULAN}

Hasil uji yang diperoleh, kadar air bioadsorben dari kulit durian yakni sebesar $10,61 \%$ dan kadar abu yakni sebesar $1,04 \%$. Untuk hasil uji SEM perbesaran 2500x, morfologi bioadsorben dari kulit durian mempunyai tektur yang tidak merata, kisaran ukuran rongga/ pori di antara 1,688-5,151 $\mu \mathrm{m}$. Sedangkan hasil analisis komposisi kimia, bioadsorben dari kulit durian memiliki komponen $\mathrm{C}, \mathrm{O}, \mathrm{Na}, \mathrm{K}$ dan $\mathrm{Ca}$.

Bioadsorben dari kulit durian mampu menyerapan logam $\mathrm{Fe}$ dan $\mathrm{Zn}$ pada air sumur hingga kadar akhir logam $\mathrm{Fe}$ mencapai 0, $169 \mathrm{mg} / \mathrm{L}$ dan kadar akhir logam $\mathrm{Zn}$ mencapai < $0,001 \mathrm{mg} / \mathrm{L}$.

\section{UCAPAN TERIMA KASIH}

Penulis mengucapkan terima kasih kepada Kepala Balai dan Kepala Seksi Teknologi Industri Baristand Industri Pontianak, rekan-rekan tim penelitian, Laboratorium SEM Fakultas MIPA Institut Teknologi Bandung (ITB), Laboratorium Air Baristand Industri Pontianak dan semua pihak yang telah membantu sehingga penelitian ini dapat terlaksana dan tulisan ini dapat diterbitkan.

\section{DAFTAR PUSTAKA}

[1] Aditya, Anang. 2014. Karakteristik Fisika-Kimia Pengomposan Limbah Kulit Durian (Durio Zibethinus L.) Menggunakan Cairan Rumen Sapi. Jurnal Protobiont.Vol. 3(3): 75-80.

[2] Hanum, F., Rikardo Jgst Gultom dan Maradona Simanjuntak. 2017. Adsorpsi Zat Warna Metilen Biru dengan Karbon Aktif dari Kulit Durian Menggunakan $\mathrm{KOH}$ dan $\mathrm{NaOH}$ sebagai Aktivator. Jurnal Teknik Kimia USU, Vol 6(1): 49-55.

[3] Kusumaningtyas, R.D., Hardi Suyitno dan Ria Wulansarie. 2017 Pengolahan Limbah Kulit Durian di Wilayah Gunungpati Menjadi Biopestisida yang Ramah Lingkungan. Jurusan Teknik Kimia. Fakultas Teknik. Universitas Negeri Semarang.

[4] Hatta, V, 2007. Manfaat kulit durian selezat buahnya, Karya Ilmiah, Universitas Lampung, Lampung.

[5] Anindyawati, T, 2010, Potensi Selulase dalam Mendegradasi Lignoselulosa Limbah Pertanian untuk Pupuk Organik, Jurnal Berita Selulosa, Vol. 45(2), hal. 70-77.

[6] Han JS. 1999. Stormwater Filtration of Toxic Heavy Metal Ions Using Lignocellulosic Materials Selection Process, Fiberization, Chemical Modification and Mat Formation. USA: Departement of Agriculture. Forest Service. Forest Product Laboratory. Madison. Wisconsin.

[7] Richana N, Lestina P, Irawadi T. 2004. Karakterisasi Lignoselulosa dari Limbah Tanaman Pangan dan Pemanfaatannya untuk Pertumbuhan Bakteri RXA III-5 Penghasil Xilanase. Balai Besar Penelitian dan Pengembangan Pascapanen. Institut Pertanian Bogor. Jawa Barat 23:112.

[8] Asip, F., Mardhiah, R., dan Husna. 2008. Uji Efektivitas Cangkang Telur dalam Mengadsorpsi Ion Fe dengan Proses Batch, Jurnal Teknik Kimia, 15(2), 22-26.

[9] Soemirat, J,2001. Pencemaran Lingkungan, Renika Cipta, Jakarta

[10] Febrina, Laila dan Astrid Ayuna. 2015. Studi Penurunan Kadar Besi (Fe) dan Mangan (Mn) Dalam Air Tanah Menggunakan Saringan Keramik. Jurnal Teknologi Universitas Muhammadiyah Jakarta Vol 7(1): 35-44.

[11] Sutrisno. (2008). Penentuan salinitas air dan jenis pakan alami yang tepat dalam pemeliharaan benih ikan sidat (anguilla bicolor). Jurnal Akuakultur Indonesia, 7(1): 71-77.

[12] Slamet, J. S. (1994). Kesehatan lingkungan. Yogyakarta: UGM-Press.

[13] Siregar, Y.D.I., Rudi Heryanto, Adi Riyadhi, Tri Heny Lestari dan Nurlela. 2015. Karakteristik Karbon Aktif Asal Tumbuhan dan Tulang Hewan Menggunakan FTIR dan Analisis Femometrik. Jurnal Kita Valensi: Jurnal Penelitian dan Pengembangan Ilmu Kimia. Vol 1(2): 103-116.

[14] Kusdarini, Esthi, Agus Budianto dan Desyana Ghafarunnisa. 2017. Produksi Karbon Aktif dari Batubara Bituminus dengan Aktivasi 
Tunggal H3PO4, Kombinasi H3PO4-NH4HCO3 dan Termal. Jurnal REAKTOR. Vol 17(2):74-80.

[15] Rao, M, M. Ramesh, A. Rao G, P, C. Seshaiah, K (2006). Removal of copper and cadmium from the aqueous solutions by activated carbon derived from Ceiba pentandra hulls. Journal of Hazardous Materials B129 (2006) 123-129.

[16] Oktasari, Ade. 2018. Kulit Kacang Tanah (Arachis hypogaea L.) sebagai Absorben Ion $\mathrm{Pb}$ (II). ALKIMIA : Jurnal Ilmu Kimia dan Terapan. Vol. 2(1): 17-27.

[17] Afrianita, Reri. 2012. Studi Penentuan Kondisi Optimum Fly Ash Sebagai Adsorben dalam Menyisihkan Logam Berat Timbal $(\mathrm{Pb})$. Jurnal Teknik Lingkungan UNAND 9 (1) :37-43.ISSN 1829-6084.

[18] Hanum, F., Rikardo Jgst Gultom dan Maradona Simanjuntak. 2017. Adsorpsi Zat Warna Metilen Biru dengan Karbon Aktif dari Kulit Durian Menggunakan $\mathrm{KOH}$ dan $\mathrm{NaOH}$ sebagai Aktivator. Jurnal Teknik Kimia USU, Vol 6(1): 49-55. 
JURNAL TEKNOLOGI PROSES DAN INOVASI INDUSTRI, VOL. 4, NO. 1, JULI 2019 